\title{
Ginseng, a Potentially Therapeutic Drug in $\gamma$-Irradiated Whole Blood Culture
}

\section{Z. S. Said, S. A. Montaser* and M. M. Ahmed*}

Radiation Safety Dep., Nuclear \& Radiological Regulatory Authority (NRRA) and *Radiation Biology Dept., National Centre for Radiation Research and Technology (NCRRT), Atomic Energy Authority, P. O. Box: 29 Nasr City, Egypt.

G INSENG is commonly used as herbal medicines with wide range of beneficial effects. It is also approved as effective agent against radiation hazards, through its immunomodulating role in irradiated experimental animals.

This experiment aimed to assess cytogenetic and biochemical changes of ginseng at a working dose $(100 \mu \mathrm{g} / \mathrm{ml})$ in suppressing radiation effects of human peripheral blood. The treatment times were 6,48 and $72 \mathrm{~h}$ after $\gamma$-irradiation at dose of 4 Gy (the last two treatment periods were done through blood culture). Triple blood cultures for each blood sample were set up. Cytogenetic investigations were evaluated using chromosome aberration (CA) analysis and cytokinesis-block micronucleus assay (CBMN). The levels of malondialdhyde (MDA), superoxide dismutase (SOD) and nitric oxide (NO) were estimated in blood plasma and in 48 \& $72 \mathrm{~h}$ blood cultures. In addition, immune function response was assessed by estimation of the levels of (Immunoglobulin G) IgG and IgM for the same treatment periods.

Ionizing irradiation induced significant decrease of SOD activity. While, CA (dicentric, ring, breaks and polyploidy), micronucleus (MN), MDA level and NO concentration were significantly increased. For IgG and IgM, there is temporary over-production of them after $6 \mathrm{~h}$ of irradiation, and then their levels decreased in the periods $48 \& 72 \mathrm{~h}$ within the cultures.

Ginseng post-irradiation treatment exhibits increase in the level of IgG and IgM production, and improvement in NO concentration. In addition, there is reduction in the levels of lipid peroxidation (LPO), CA and MN frequencies. Results concluded that ginseng has antimutagenic effect and benefit against oxidative stress involved by irradiation.

Keywords: Ginseng, $\gamma$-rays, blood culture, immunoglobulin, chromosome. 
Ginsenosides are the main pharmacologically active ingredient responsible for the four major action of ginseng: vasorelaxation, antioxidation, anti-inflammation and anticancer effect. Ginseng polysaccharides also possess antitumor effect through modulation of innate immunity. Ginseng polysaccharides (present in 15\% of ginseng root), including neutral and acidic polysaccharide are water-soluble. It has been reported that panax ginseng ( $\mathrm{P}$. ginseng) polysaccharides contain starchlike polysaccharide and pectin (Zhang et al., 2009).

Numerous studies have been carried out on the effects of ionizing radiation on chromosome changes in blood components. From x-irradiation ( 0.25 to $5 \mathrm{~Gy})$ of human, a non-linear relationship between radiation dose and CA of the dicentric, interstitial deletion and ring type, and a linear relationship between radiation dose and CA of the gap and break type. The frequency of cell changes increased as a linear function of the dose, while the frequency of breaks increased as a non-linear function of the dose. In another investigation of a relationship between yields of $\mathrm{MN}$ and radiation dose, $\mathrm{MN}$ were induced in lymphocytes by exposing human blood samples in vitro to various doses of Cs-137 gamma-rays. It seems, according to Balasem and Ali (1991), that there is a correlation between the yields of $\mathrm{MN}$ in mononuclear cells and the corresponding doses of radiation. Similarly, experiments were conducted by Kligerman et al. (1988) on the chromosome damaging effects of Co-60 gamma radiation on human peripheral blood lymphocytes (PBLs). Either whole blood or isolated and pelleted mononuclear leukocytes (MNLs) were irradiated in a Co-60 unit to yield exposures of 1, 2, 3, or 4Gy.

Immune globulins (Igs) are synthesized by B lymphocytes (B cells) and are both synthesized and secreted by plasma cells. Normal individuals express five Igs classes or isotypes. IgM, the heaviest, is present as either a cell-surfacebound monomer or as a secreted pentamer. $\operatorname{IgD}$, a monomer, is almost exclusively displayed on B cell surfaces. Human $\operatorname{IgG}$ is a monomer present in four subclasses; $\operatorname{IgG} 1, \mathrm{IgG} 2, \mathrm{IgG} 3$ and $\mathrm{IgG} 4$. Monomeric $\operatorname{IgA}$ is present in the serum and in its dimeric form is found in association with mucosal surfaces and secretion. IgE is present in relatively low serum concentration most is absorbed onto the surface of mast cells, basophiles, and eosinophils (Doan et al., 2008). The observed reduction in $\mathrm{IgG}$ levels indicates that the mechanisms responsible for IgG synthesis are somewhat disturbed, which may be associated with the Egypt. J. Rad. Sci. Applic., Vol. 28, No. 1-2 (2015) 
effect of ionizing radiation on B cell and T helper 2 (Th2.) The influence may be associated with the expression of the adhesion particles involved in the communication of those cells during IgG synthesis, in the production of Th2 cytokines at that stage of the humoral response, or may result from the direct effect on gene expression and $\operatorname{IgG}$ synthesis. As stated earlier, B cell is more sensitive to ionizing radiation than lymphocytes $T$ (Gridley et al., 2002). In addition, lymphocytes Th2 responsible for class switching of produced Igs are more sensitive to radiation than population of Th1, whose role is mainly associated with cellular-type response (Dekruyff et al., 1995). Currently, it has been reported that ginsenoside-based nanoparticles (ginsomes) played a role as a novel adjuvant and up regulated T-helper 1 (Th1) and Th2 immune response in imprinting control region mice. The ginsomes were spherical with diameters ranging from 70 to $107 \mathrm{~nm}$ and contained ginsenosides $\mathrm{Rb} 2, \mathrm{Rc}, \mathrm{Rb} 1$, and $\mathrm{Rd}$. The ginsomes promoted significantly higher IgG responses increased the levels of specific IgG1, IgG2a, IgG2b, and IgG3, as well as $\mathrm{T}$ and B lymphocyte proliferation. The enhanced IgG titer and subclass levels paralleled the increased production of interferon gamma IFN- $\gamma$ (Th1 cytokine) and interleukin-5 (Th2 cytokine). Therefore, ginsomes as an adjuvant are assumed to up-regulate both Th1 and Th2 immune responses (Song et al., 2009).

Chronic inflammation is associated with high cancer risk. At the molecular level, free radicals and aldehydes, produced during chronic inflammation can induce deleterious gene mutation and post translational modification of key cancer-related proteins. Other products of inflammation, including cytokines, growth factors, and transcription factors such as, nuclear factor kappa, control the expression of cancer gene (e.g suppressor genes and oncogenes) and key inflammatory enzymes such as inducible NO synthase and cyclooxygenase-2. These enzymes in turn directly influence reactive oxygen species (ROS) (Hofseth and Wargovich, 2007).

The radiation induction of LPO processed via oxidative conversion of cell lipid constituents to several products includes MDA, a highly toxic molecule, serves as an index of oxidative damage (Bakan et al., 2002) and has inhibitory action on protective enzymes (Taysi et al., 2003). NO is synthesized from L-arginine by the L-arginine-nitric oxide pathway (Palmer et al., 1988) and is converted to nitrite and nitrate in oxygenated solutions.

Egypt. J. Rad. Sci. Applic., Vol. 28, No. 1-2 (2015) 
Many results are in accordance with the studies cited above claiming enhancement of host resistance due to ginseng treatment, as they indicate that P. ginseng might display modulatory effects on the innate immune defence by stimulation of the inducible NO synthesis in macrophages.

\section{Materials and Methods}

\section{Chemicals}

The chemicals of the blood cultures were purchased from GIBCO-BRL, USA. FA, cytochalasin-B, heat-inactivated foetal calf serum and other chemicals and solvents were purchased from Sigma/ Alderch Chemical Co., St. Louis, USA. P. ginseng, a product, was purchased from EIPICO Pharmaceutical Company, Egypt, which available in the form of capsules with the trade name (Ginsana100). Each capsule contained 100mg of the dried roots of P. ginseng. The contents of the capsule was withdrawn by a syringe and dissolved in distilled water.

\section{Blood sampling}

To overcome possible inter-individual variability in response to treatments, blood sample was obtained from matching three healthy females (average age 35 years and non-smokers) who gave an informed consent for participation in the study. The donors were selected according to current International Programme on Chemical Safety guidelines for the monitoring of genotoxic effects of carcinogens in humans (Albertini et al., 2000). Venous blood was collected under sterile conditions in heparinised vacutainer tubes $(\mathrm{V}=5 \mathrm{ml}$, Becton Dickinson, USA) containing lithium heparin as anticoagulant.

\section{Experimental design}

Blood were divided into 4 groups; in each group, 3 samples were processed $(\mathrm{n}=3)$. One test dose $(100 \mu \mathrm{g} / \mathrm{ml})$ of ginseng were added to the grouped normal blood. Group 1: control blood, group 2: Ginseng $(100 \mu \mathrm{g} / \mathrm{ml})$ which treated with ginseng immediately post irradiation time. Group 3: Irradiated blood samples with 4Gy (dose rate of 3.16Gy/ min), group 4: Irradiation \& Ginseng $(100 \mu \mathrm{g} / \mathrm{ml})$ which treated with ginseng immediately post irradiation of the blood. After irradiation and treatment for $6 \mathrm{~h}$, blood samples were divided into two parts: the first one was added to the culture and the second one obtained and separated by centrifugation (Sorvall TC centrifuge, Hamburg, Germany) at $750 \mathrm{~g}$ at room Egypt. J. Rad. Sci. Applic., Vol. 28, No. 1-2 (2015) 
temperature for 10min. LPO products and immunological parameters were measured in plasma and culture ( $48 \& 72 \mathrm{~h})$.

\section{Blood culture}

To $0.5 \mathrm{ml}$ of the whole blood, $5 \mathrm{ml}$ culture medium (RPMI-1640) supplemented with $20 \%$ FCS, $200 \mathrm{~m} \mathrm{M} \mathrm{l-glutamine,} \mathrm{penicillin} 100$ units/ ml and streptomycin $100 \mu \mathrm{g} / \mathrm{ml}$ were added in $15 \mathrm{ml}$ conical tubes. Phytohaemagglutinin-M (PHA-M); $0.2 \mathrm{ml}$ was added to the culture to initiate cell division. Then, cells were incubated at $37^{\circ} \mathrm{C}$.

\section{Irradiation source}

${ }^{137} \mathrm{Cs} \gamma$-rays source was provided by the NCRRT, Egypt, manufactured by the Atomic Energy of Canada. The dose rate was 3.16Gy/ min. The adjusted dose was $4 \mathrm{~Gy}$. The samples were kept at $37^{\circ} \mathrm{C}$ after irradiation immediately till the treatment periods with ginseng started.

\section{Chromosome aberration test (CA)}

The culture setup for CA was previously described by Prasad et al. (2005). Colcemid at a final concentration of $0.1 \mu \mathrm{g} / 5 \mathrm{ml}$ was added to the initiated blood culture at $46 \mathrm{~h}$ to block the cells at metaphase stage. The cells were harvested at $48 \mathrm{~h}$, given hypotonic treatment for $10 \mathrm{~min}$ and transferred to a pre-cooled slide. The slides were stained with $10 \%$ Giemsa and examined (10× 100 oil immersion) to score CA. In each group, a total of 300 cells (100 from each experiment) were scored and the frequency of cells with aberrations and dicentrics were recorded.

\section{Cytokinesis-blocked micronucleus assay (CBMN)}

The presence of $\mathrm{MN}$ in a BNC was assayed by blocking the cell at the cytokinesis stage by the method of Fenech and Morley (1985) and Fenech et al. (2003). Blood culture was set as described previously. Cytochalasin-B $(3 \mu \mathrm{g} / 5 \mathrm{ml}$ culture) was added to the culture at $48 \mathrm{~h}$ after the initiation. The cells were further incubated at $37^{\circ} \mathrm{C}$ for another $24 \mathrm{~h}$. At the harvest time, after centrifugation at $1500 \mathrm{rpm}$ for $5 \mathrm{~min}$, cell pellets were treated with $5 \mathrm{ml}$ of mild hypotonic solution $(0.1 \mathrm{MKCl})$ was used for $3 \mathrm{~min}$, and a further $10 \mathrm{~min}$ of centrifugation at $800 \mathrm{rpm}$. After another centrifugation, cells were washed once with the fixative solution $(3: 1(\mathrm{v} / \mathrm{v})$ methanol: acetic acid). Fixed cells were dropped gently on clean microscope slides, air-dried and stained with $10 \%$ Giemsa for $8 \mathrm{~min}$. In each group a total of $1500 \mathrm{BNC}$ (500 from each experiment) were scored and the 
frequency of cells with one $\left(\mathrm{MN}_{1}\right)$, two $\left(\mathrm{MN}_{2}\right)$ and three $\left(\mathrm{MN}_{3}\right)$ micronuclei were recorded.

\section{Biochemical estimations}

MDA, were measured by Ohkawa et al. (1979) method. In addition, SOD was measured according to Weydert and Cullen (2010) and NO was measured by Nitrite analysis which determined by spectrophotometr using the Griess reagent $(0.5 \%$ sulfanilic acid, $0,002 \% \mathrm{~N}-1$-naphtyl-ethylenediamine dihydrochloride, $14 \%$ glacial acetic acid) in supernatants. Absorbance was measured at $550 \mathrm{~nm}$ with baseline correction at $650 \mathrm{~nm}$ and nitrite concentration was determined using sodium nitrite as a standard (Green et al., 1982).

\section{Immunological estimation}

IgG and IgM were estimated in plasma and culture by Radial Immunediffusion method (RID), according to Lentner (1984). Kits was purchased from BINDRID which is a trademark of the binding site group Ltd. Birmingham, UK.

\section{Radial Immune-diffusion}

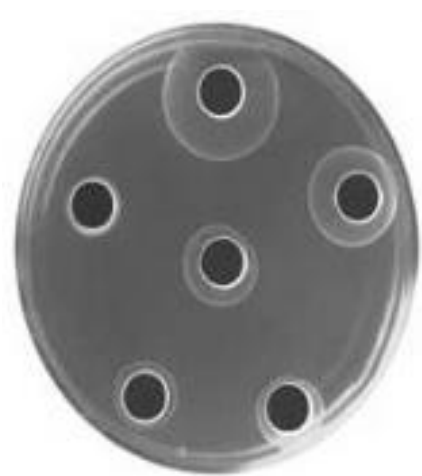

Fig. 1. RID depends on radially diffusion of antigen from well and forms a ring shaped band of precipitation. The halo of precipitation diameter gives the estimate of antigen concentration.

-Radial immune-diffusion is a variation of the agar.

-Precipitation technique is used in clinical immunology for the detection and quantitation of all classes

of immunoglobulin's complement, ceroplastic transferring and other serum components.

\section{Statistical analysis}

Data are presented as distribution analysis, means \pm S. E. and analysed using two ways analysis of variance " $F$ " test according to Abramowitz and Stegun (1972). The level for statistical significance was $P<0.05$.

Egypt. J. Rad. Sci. Applic., Vol. 28, No. 1-2 (2015) 


\section{Results}

Table 1. recorded significantly increasing of CA frequencies in human lymphocytes culture exposed to $4 \mathrm{~Gy}$ of $\gamma$-rays, comparing to control and ginseng groups.

TABLE 1. CA analysis in human blood culture treated in-vitro with ginseng $(100 \mu \mathrm{g} / \mathrm{ml})$ after $4 \mathrm{~Gy} \gamma$-rays exposure (100metaphases/individual).

\begin{tabular}{|c|c|c|c|c|c|c|c|c|}
\hline \multirow{2}{*}{ Groups } & \multicolumn{2}{|c|}{ Break } & \multicolumn{2}{|c|}{ Fragment } & \multirow{2}{*}{ Dicen } & \multirow{2}{*}{ Ring } & \multirow{2}{*}{ Polyp } & \multirow{2}{*}{ Total } \\
\hline & Chs & Chd & Chs & Chd & & & & \\
\hline Control & $\begin{array}{c}0.3 \pm \\
0.3\end{array}$ & $\begin{array}{c}1.3 \pm \\
0.3\end{array}$ & $\begin{array}{c}0.3 \pm \\
0.3\end{array}$ & $\begin{array}{c}0.7 \pm \\
0.3\end{array}$ & 00 & 00 & 00 & $\begin{array}{c}2.7 \pm \\
0.3\end{array}$ \\
\hline Ginseng & $\begin{array}{c}0.7 \pm \\
0.3\end{array}$ & $\begin{array}{c}1.67 \pm \\
0.3\end{array}$ & $\begin{array}{l}1 \pm \\
0.0\end{array}$ & $\begin{array}{c}0.3 \pm \\
0.3\end{array}$ & 00 & 00 & 00 & $\begin{array}{c}3.7 \pm \\
0.3\end{array}$ \\
\hline Irradiated & $\begin{array}{c}13 \pm \\
0.53 \\
\mathbf{a}, \mathbf{b}\end{array}$ & $\begin{array}{c}8.7 \pm \\
0.8 \\
\mathbf{a}, \mathbf{b}\end{array}$ & $\begin{array}{c}18.7 \pm \\
0.9 \\
\mathbf{a}, \mathbf{b}\end{array}$ & $\begin{array}{c}6.7 \pm \\
0.9 \\
\mathbf{a}, \mathbf{b}\end{array}$ & $\begin{array}{c}.3 \pm \\
0.3 \\
\mathbf{a}, \mathbf{b}\end{array}$ & $\begin{array}{c}2.7 \pm \\
0.3 \\
\mathbf{a}, \mathbf{b}\end{array}$ & $\begin{array}{l}9 \pm \\
1.6 \\
\mathbf{a}, \mathbf{b}\end{array}$ & $\begin{array}{c}63.0 \pm \\
0.1 \\
\mathbf{a}, \mathbf{b}\end{array}$ \\
\hline $\begin{array}{c}\text { Rad. \& } \\
\text { Ginseng }\end{array}$ & $\begin{array}{c}11 \pm \\
1.5 \\
\mathbf{a}, \mathbf{b}\end{array}$ & $\begin{array}{c}6.7 \pm \\
0.9 \\
\mathbf{a , b}\end{array}$ & $\begin{array}{c}14.7 \pm \\
0.3 \\
\mathbf{a}, \mathbf{b}, \mathbf{c}\end{array}$ & $\begin{array}{c}6.3 \pm \\
0.9 \\
\mathbf{a}, \mathbf{b}\end{array}$ & $\begin{array}{c}3.3 \pm \\
0.3 \\
\mathbf{a}, \mathbf{b}\end{array}$ & $\begin{array}{c}1.7 \pm \\
0.3 \\
\mathbf{a}\end{array}$ & $\begin{array}{c}7.7 \pm \\
0.4 \\
\mathbf{a , b}\end{array}$ & $\begin{array}{c}51.3 \pm \\
1.5 \\
\mathbf{a , b}, \mathbf{c}\end{array}$ \\
\hline
\end{tabular}

a: Significant when compared with control group.

b: Significant when compared with ginseng group.

c: Significant when compared with radiation group.

Chs: Chromosome.

Rad: Radiation.

Dicen: Dicentric.

Polyp: Polyploidy.

Irrad: Irradiation.

Chd: Chromatid.

Ginseng $(100 \mu \mathrm{g} / \mathrm{ml})$ with treatment periods $(48 \mathrm{~h})$ reduced all the CA yields after irradiation. Also, dicentrics frequencies in irradiated and ginseng groups reduced from $4.3 \%$ to $3.3 \%$, compared to irradiated group alone and the total aberrations were significantly decreased from $63 \%$ to $51.3 \%$. Table 2 . shows that ginseng treatment at dose of $100 \mu \mathrm{g} / \mathrm{ml}$ concentration and for $72 \mathrm{~h}$ period reduce the average number of $\mathrm{MN} /$ total $\mathrm{BNC}$ with percentage 25.7. In irradiated group, the expression of $3 \mathrm{MNs}$ detected with frequency $0.6 \%$, and it was reduced with ginseng treatment to $0.3 \%$. While Table 3. represents LPO levels as MDA in plasma treated with Ginseng $100 \mu \mathrm{g} / \mathrm{ml}$ after radiation exposure. The investigations were carried out at $6 \mathrm{~h}$ after irradiation and treatment for plasma and $48 \& 72 \mathrm{~h}$ for culture, the results in $(\mu \mathrm{mol} / \mathrm{L})$ were demonstrated as mean $\pm \mathrm{S}$. E. Data revealed significant elevation in MDA levels in both plasma and culture (48\&72h) in irradiated group when compared with control and ginseng groups. While, groups treated with ginseng after irradiation recorded significant improvement in plasma MDA level as compared with irradiated group.

Egypt. J. Rad. Sci. Applic., Vol. 28, No. 1-2 (2015) 
TABLE 2. Distribution analysis of CBMN assay in human blood culture treated invitro with ginseng $(100 \mu \mathrm{g} / \mathrm{ml})$ after $4 \mathrm{~Gy} \gamma$-rays exposure (BNC/ individual).

\begin{tabular}{|c|c|c|c|c|c|c|}
\hline \multirow{2}{*}{ Groups } & \multirow{2}{*}{$\begin{array}{c}\text { Total No. } \\
\text { of MN }\end{array}$} & \multicolumn{3}{|c|}{ BNC+ MN } & Total No. & $\begin{array}{c}\text { Average No. } \\
\text { of MN/ BNC }\end{array}$ \\
\hline Control & 10 & 8 & 2 & 0 & 12 & 0.012 \\
\hline Ginseng & 13 & 10 & 3 & 0 & 16 & 0.016 \\
\hline Irradiated & 248 & 198 & 41 & 9 & 307 & 0.307 \\
\hline $\begin{array}{c}\text { Rad. \& } \\
\text { Ginseng }\end{array}$ & 190 & 156 & 30 & 4 & 228 & 0.228 \\
\hline
\end{tabular}

Legends as in Table 1.

SOD activity recorded significant decrease in plasma and culture after irradiation, accompanied by elevated levels of NO in plasma and culture. Treatment with ginseng for the three periods showed significant increase in SOD and decrease in NO levels.

TABLE 3. MDA, SOD and NO concentrations in human blood plasma $\&$ culture $(48 \& 72 \mathrm{~h})$ treated in-vitro with ginseng $(100 \mu \mathrm{g} / \mathrm{ml})$ after $4 \mathrm{~Gy} \gamma$-rays exposure.

\begin{tabular}{|c|c|c|c|c|c|c|c|c|c|}
\hline \multirow[b]{2}{*}{ Groups } & \multicolumn{3}{|c|}{ MDA $(\mu \mathrm{mo} 1 / \mathrm{L})$} & \multicolumn{3}{|c|}{ SOD $(\mathrm{U} / \mathrm{ml})$} & \multicolumn{3}{|c|}{ NO $(\mu \mathrm{mol} / \mathrm{L})$} \\
\hline & Plasma & $\begin{array}{l}\text { Cul } \\
8 \mathrm{~h}\end{array}$ & $\begin{array}{l}\text { Cul } \\
72 \mathrm{~h}\end{array}$ & Plasma & $\begin{array}{l}\text { Cul } \\
48 h\end{array}$ & $\begin{array}{l}\text { Cul } \\
72 \mathrm{~h}\end{array}$ & Plasma & $\begin{array}{l}\text { Cul } \\
48 h\end{array}$ & $\begin{array}{l}\mathrm{Cul} \\
72 \mathrm{~h}\end{array}$ \\
\hline Control & $\begin{array}{c}75.7 \pm \\
2.9\end{array}$ & $\begin{array}{c}15.4 \pm \\
0.1\end{array}$ & $\begin{array}{c}15.6 \pm \\
0.2\end{array}$ & $\begin{array}{c}4.5 \pm \\
0.2\end{array}$ & $\begin{array}{c}1.5 \pm \\
0.2\end{array}$ & $\begin{array}{c}1.5 \pm \\
0.1\end{array}$ & $\begin{array}{c}25.5 \pm \\
0.4\end{array}$ & $\begin{array}{c}15.7 \pm \\
0.4\end{array}$ & $\begin{array}{c}15.7 \pm \\
0.3\end{array}$ \\
\hline Gins & $\begin{array}{c}65.1 \pm \\
1.7 \\
a\end{array}$ & $\begin{array}{c}14.5 \pm \\
0.2 \\
\mathbf{a}\end{array}$ & $\begin{array}{c}14.7 \pm \\
0.1 \\
\mathbf{a}\end{array}$ & $\begin{array}{c}4.6 \pm \\
0.2\end{array}$ & $\begin{array}{c}1.6 \pm \\
0.2\end{array}$ & $\begin{array}{c}1.6 \pm \\
0.2\end{array}$ & $\begin{array}{c}24.8 \pm \\
0.4\end{array}$ & $\begin{array}{c}14.7 \pm \\
0.1\end{array}$ & $\begin{array}{c}14.1 \pm \\
0.1 \\
\mathbf{a}\end{array}$ \\
\hline Irrad & $\begin{array}{c}111.4 \pm \\
0.2 \\
\text { a,b }\end{array}$ & $\begin{array}{c}24.1 \pm \\
0.1 \\
\mathbf{a , b}\end{array}$ & $\begin{array}{c}24.4 \pm \\
0.2 \\
\mathbf{a , b}\end{array}$ & $\begin{array}{c}3.1 \pm \\
0.0 \\
\mathbf{a , b}\end{array}$ & $\begin{array}{c}0.6 \pm \\
0.1 \\
\mathbf{a}, \mathbf{b}\end{array}$ & $\begin{array}{c}0.7 \pm \\
0.1 \\
\mathbf{a , b}\end{array}$ & $\begin{array}{c}61.6 \pm \\
0.7 \\
\mathbf{a , b}\end{array}$ & $\begin{array}{c}20.3 \pm \\
0.4 \\
\text { a,b }\end{array}$ & $\begin{array}{c}21.6 \pm \\
0.3 \\
\mathbf{a , b}\end{array}$ \\
\hline $\begin{array}{l}\text { Rad. \& } \\
\text { Ginseng }\end{array}$ & $\begin{array}{c}82.9 \pm \\
1.5 \\
\mathbf{a}, \mathbf{b}, \mathbf{c}\end{array}$ & $\begin{array}{c}17.1 \pm \\
0.3 \\
\text { a,b,c }\end{array}$ & $\begin{array}{c}16.6 \pm \\
0.2 \\
\mathbf{a , b}, \mathbf{c}\end{array}$ & $\begin{array}{c}4.10 \pm \\
0.1 \\
\mathbf{c}\end{array}$ & $\begin{array}{c}1.0 \pm \\
0.1 \\
\mathbf{a}, \mathbf{b}, \mathbf{c}\end{array}$ & $\begin{array}{c}0.9 \pm \\
0.1 \\
\mathbf{a , b}\end{array}$ & $\begin{array}{c}39.3 \pm \\
0.3 \\
\mathbf{a , b}, \mathbf{c}\end{array}$ & $\begin{array}{c}16.3 \pm \\
0.2 \\
\text { b,c }\end{array}$ & $\begin{array}{c}17.5 \pm \\
0.3 \\
\text { a,b,c }\end{array}$ \\
\hline
\end{tabular}

Legends as in Table 1.

Cul: Culture

While Table 3. represents MDA level in plasma treated with Ginseng $100 \mu \mathrm{g} / \mathrm{ml}$ after radiation exposure. The investigations were carried out at $6 \mathrm{~h}$ after irradiation and treatment for plasma and $48 \& 72 \mathrm{~h}$ for culture, the results in $(\mu \mathrm{mol} / \mathrm{L})$ were demonstrated as mean \pm S. E. Data revealed significant elevation in MDA levels in both plasma and culture $(48 \& 72 \mathrm{~h})$ in irradiated group when compared with control and ginseng groups. While, groups treated

Egypt. J. Rad. Sci. Applic., Vol. 28, No. 1-2 (2015) 
with ginseng after irradiation recorded significant improvement in plasma MDA level as compared with irradiated group. SOD activity recorded significant decrease in plasma and culture after irradiation, accompanied by elevated levels of NO in plasma and culture. Treatment with ginseng for the three periods showed significant increase in SOD and decrease in NO levels.

TABLE 4. IgG and IgM levels in human blood plasma $\&$ culture $(48 \& 72 \mathrm{~h})$ treated in-vitro with ginseng $(100 \mu \mathrm{g} / \mathrm{ml})$ after $4 \mathrm{~Gy} \gamma$-rays exposure.

\begin{tabular}{|c|c|c|c|c|c|c|}
\hline \multirow{2}{*}{ Groups } & \multicolumn{3}{|c|}{ IgG $(\mu \mathrm{mol} / \mathrm{L})$} & \multicolumn{3}{c|}{ IgM $(\mu \mathrm{mol} / \mathrm{L})$} \\
\cline { 2 - 7 } & Plasma & Cul 48 & Cul 72 & Plasma & Cul 48 & Cul 72 \\
\hline \multirow{2}{*}{ Control } & $6241.0 \pm$ & $2192.3 \pm$ & $1875.3 \pm$ & $858.3 \pm$ & $369.7 \pm$ & $260.3 \pm$ \\
& 1.0 & 1.20 & 2.6 & 1.8 & 1.7 & 1.5 \\
\hline \multirow{3}{*}{ Ginseng } & $6240.0 \pm$ & $1875.0 \pm$ & $1775.0 \pm$ & $605.0 \pm$ & $393.0 \pm$ & $242.3 \pm$ \\
& 2.9 & 3.2 & 2.9 & 1.2 & 1.2 & 1.2 \\
& & $\mathbf{a}$ & $\mathbf{a}$ & $\mathbf{a}$ & $\mathbf{a}$ & $\mathbf{a}$ \\
\hline \multirow{3}{*}{ Irradiated } & $16200.0 \pm$ & $1561.3 \pm$ & $1250.0 \pm$ & $1491.7 \pm$ & $268.3 \pm$ & $170.0 \pm$ \\
& 5.8 & 0.6 & 2.9 & 4.4 & 2.5 & 2.89 \\
& $\mathbf{a , b}$ & $\mathbf{a , b}$ & $\mathbf{a , b}$ & $\mathbf{a , b}$ & $\mathbf{a , b}$ & $\mathbf{a , b}$ \\
\hline \multirow{2}{*}{ Radiation \& } & $10800.0 \pm$ & $1813.0 \pm$ & $1612.3 \pm$ & $740.3 \pm$ & $279.3 \pm$ & $194.0 \pm$ \\
Ginseng & 6.0 & 3.8 & 1.5 & 1.5 & 1.2 & 2.1 \\
& $\mathbf{a , b , c}$ & $\mathbf{a , b}, \mathbf{c}$ & $\mathbf{a , b , c}$ & $\mathbf{a , b , c}$ & $\mathbf{a , b , c}$ & $\mathbf{a , b , c}$ \\
\hline
\end{tabular}

Legend as in table 1

Table 4. represents the levels of IgG and IgM. It well noticed that a sudden production of IgG and IgM after $6 \mathrm{hrs}$ post irradiation, were observed, but their levels significantly decreased in culture $(48 \& 72 \mathrm{~h}$ ) more than those of control and ginseng groups. However, treatment with ginseng, improved its levels after irradiation.

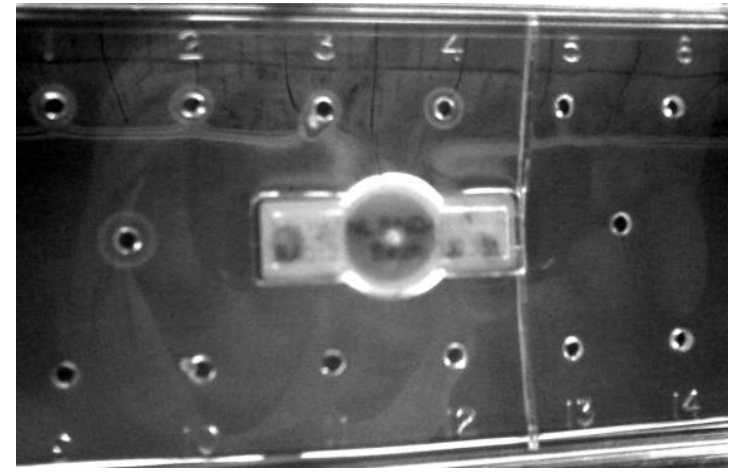

Fig. 2. RID, a variation of the agar precipitation technique is used in detection and quantification of IgG and IgM in plasma and blood culture (48 \& 72h).

Egypt. J. Rad. Sci. Applic., Vol. 28, No. 1-2 (2015) 


\section{Discussion}

Ginseng attains growing popularity as herbal remedy in Western Europe and in northern America on health are attributed to ginseng root extract. The beneficial effects of ginseng have been demonstrated in cancer, diabetes, cardiovascular diseases and have been used for promoting immune function, central nervous system function, relieving stress, and for its antioxidant activities (Jung and Jin 1996).

The radiation can directly damage the structure and functions of the bioactive molecules in cells and tissues, eliciting disorder and apoptosis (Jensh, 1985). Beside, the radiation may cause bone marrow suppression and depletion of peripheral blood lymphocytes, and lead to severely inhibit the function of immune system.

Deoxyribonucleic acid (DNA) damage occurs either by direct ionization or indirectly through generation of free radicals that attack DNA, resulting in singlestrand breaks and oxidative damage to sugar and base residues (Breen and Murphy, 1995), which may later be converted into DNA double strand breaks. It is understood that the un-repaired double strand breaks will contribute to CA (Satish Rao et al., 2006). In this respect, $\gamma$-rays are exogenous DNA damaging agents cause marked increasing in CA frequency in $\gamma$-irradiated group. Endogenous agents, including ROS arising during radiation-exposure, can lead to DNA damage. If over production of ROS occur, oxidative damage could lead to radiation-induce cytotoxicity; chromosomal damage and gene mutations (Halliwell, 2002). Some nutrients and herbal drugs may influence this process by promoting the formation of the damaging agents in certain circumstances, while other components, such as hormones may function to enhance repair mechanisms (Fenech, 2005).

Table 1. \& 2. showed that ginseng treatment reduced the frequencies of CA and MN especially for fragments, dicentrics, total aberration and percentage of MN. These results are the same finding data with recent studies which demonstrated that ginseng exhibits protective activity against oxygen species in irradiated groups. It seems that the strong free radical scavenging effects of $p$. ginseng have been extensively documented by many studies (Kim et al., 2002 and Kitts et al., 2000) where the radio protective of p. ginseng has been closely linked Egypt. J. Rad. Sci. Applic., Vol. 28, No. 1-2 (2015) 
to its antioxidative capability through both chelating of transition metal ions and scavenging of free radicals responsible for DNA damage (Kim et al., 1993).

Bhosle et al. (2005) stated that ionizing radiation is known to induce oxidative stress through generation of ROS in an imbalance in pro-oxidant, antioxidant status in the cells. So, the increase in LPO levels in $\gamma$-irradiated groups might be due to the interaction of free radicals with polyunsaturated fatty acids in the phospholipids portion of cellular membranes (Prasad et al., 2005). Moreover, Kregel and Zhang (2007) reported that the decrease in the activities of SOD might be due to their utilization by the enhanced production of ROS, which interacts with the enzyme molecules causing their denaturation and partial inactivation.

Radical ions, oxides and so on cause acute radiation damage through LPO of proteins and DNA. Since NO is a free radical gas, this suggests that it may be involved in the fatal effects of irradiation. Contrary to this hypothesis, the known physiological functions of NO imply that it should prevent radiation-induced death. NO generated through combined use of LPS may increase survival rate after irradiation, if its effects are deemed positive. Alternatively, survival rate could decrease if its effects are injurious (Ohta et al., 2007).

The current study displays effects of $\gamma$-irradiation on both plasma and cell cultures ( $48 \& 72 \mathrm{~h}$ ) of blood which revealed significant elevation in MDA and NO levels and reduction of SOD activity when compared with control and ginseng groups. While, groups treated with ginseng after irradiation recorded significant improvement in all mentioned parameters level as compared with irradiated group. The observed reduction in plasma and cultures MDA and NO levels of ginseng treated \& $\gamma$-irradiated compared with its matched values in irradiated and enhancement of SOD activity recorded after ginseng administration go hand to hand with the results founded by Liu et al. (1998). Moreover, Kumar et al. (2003) found that administration of p. ginseng root extract before irradiation induced significant decrease in LPO levels and reduced the radiation hazards.

The radioprotective effect and the antioxidative potentials of ginseng has been demonstrated in several studies findings as reduction in MN, CA frequencies and improvement of LPO levels (Lee et al., 2005). 
Although the performance of previous parameters was similar in both plasma (after $6 \mathrm{~h}$ post-irradiation and treatment) and culture (48 \&72h), the levels of $\mathrm{IgG}$ and $\mathrm{IgM}$ show opposite manner. Alternatively, the humoral immune response is an immunity mediated by antibodies (Slifka et al., 1998). In this response, the immune system triggers specific B cells (mostly, plasma cells) to proliferate and secrete large amounts of specific antibodies which then fight invading microorganisms or pathogenic antigens (Slifka et al., 1998).

The results of present study illustrated that mean IgG and IgM plasma levels after irradiation (6h) were significantly higher than those of control group which may be attributed to activation of B-cell. Sinkorova et al. (2009) stated that the peripheral B-cell compartment in pigs has proved highly radiosensitive both in vivo and in vitro and $\mathrm{B}$ lymphocytes apparently represent the most radiosensitive lymphoid population. The higher concentrations of $\mathrm{IgG}$ in plasma in respect to radiation exposure might be explained by inherent features of IgG. Due its small size, IgG easily diffuses into tissues, opsonizes pathogens for engulfment by phagocytes, activate the complement system, and neutralizes antigens (Janeway and travers, 1997). On the other hand, our results indicated significant reduction of IgG and IgM concentrations in culture ( $48 \& 72 \mathrm{~h}$ ) of the studied group's postirradiation. These results are consistent with previous studies (Myers, 1991). The lower concentrations of $\mathrm{IgG}$ and $\operatorname{IgM}$ than those of control group may be explained by the long period of time for culture. Regarding IgM, the largest among Igs and the first one to interact with new antigens (Janeway and travers, 1997), the lower IgM levels than that observed for IgG in blood culture compared with their levels in plasma could have been affected by decreased immune response in blood culture after radiation exposure. This finding is consistent with that investigated by (Mc Mahon et al., 2014).

Although numerous studies describe the role of ginseng on antibody production, most of them evaluate its adjuvant potential on the secretion of specific antibodies. In general, ginseng extract successfully induced antigens specific $\operatorname{IgM}, \operatorname{IgG}$, and $\operatorname{IgA}$ antibody responses when administered orally or intra peritoneal (Liou et al., 2004 \& 2005). Ginseng extract or its purified components appear to elicit improved humoral responses against microbial invasion irrespective of administration methods or types of microbes. Moreover, gamma radiation causes suppression of the immune function, and immune Egypt. J. Rad. Sci. Applic., Vol. 28, No. 1-2 (2015) 
properties are related to cytokine production. In the present study, P. ginseng was studied to assess its effects on the immunosuppressive activities of gamma radiation. These findings indicated that Ginseng induces considerable improvement of $\mathrm{IgG}$ and $\mathrm{IgM}$ levels in blood culture (48\&72h) after gamma irradiation. Han et al. (2005) was postulated that Ginsan stimulate murine normal spleenocytes by inducing the ribonucleic acid messenger (mRNA) expressions of Th1 and Th2 type cytokines, and also restore the mRNA expression of IFN-gamma, Th1 cytokine, after its inhibition by whole-body gamma irradiation. Ginsan was found to restore the $\mathrm{T}$ lymphocytes function that had been suppressed by gamma irradiation in allogeneic mixed lymphocyte reactions. The present study extended previous research and indicated that the duration of ginseng treatment affects the immune modulatory activity of ginseng. Additionally, Previous research indicated that plasma treated with Ginseng alone exhibited a distinct effect in IgG levels (Liou and Huang, 2005). In addition, results of the present study showed that levels of IgG and IgM in plasma returned to its lower values as result of ginseng treatment after gamma radiation. Data also support the role of ginseng as an immune modulator which is obviously indicated by its effect on reducing the evoked immune response after gamma radiation exposure. Obtained data coincide with the previous study which indicated that mice treated with ginseng root extract for 5 consecutive days had reduced serum level of IgG (Liou et al., 2005).

Communally, the obtained results of this study provide a scientific background of the usefulness of ginseng as a radio protector for humans.

\section{Acknowledgment}

The authors greatly appreciate Dr. Mahmoud Refaat Ahmed Mohamed, Air force hospital, for help in blood sampling.

\section{References}

Abramowitz, M. and Stegun, I. A. (1972) Handbook of mathematical functions. Dover Publications, Inc. New York, USA, p. 925.

Albertini, R. J., Anderson, D., Douglas, G. R., Hagmor, L., Hemminki, K., Merlo, F., Natarajan, A. T., Norppa, H., Shuker, D. E. G., Tice, R., Waters, M. D. and Aitio, A. (2000) IPCS guidelines for the monitoring of genotoxic effects of carcinogens in humans. International Programme on Chemical Safety. Mutat. Res., 463, 111.

Egypt. J. Rad. Sci. Applic., Vol. 28, No. 1-2 (2015) 
Bakan, E., Taysi, S., Polat, M. F., Dalga, S., Umudum, Z. and Gumus, M. (2002) Nitric oxide levels and lipid peroxidation in plasma of patients with gastric cancer. Clin. Oncol., 32, 162.

Balasem, A. N. and Ali, A. S. (1991) Establishment of dose-response relationships between doses of Cs-137 gamma-rays and frequencies of micronuclei in human peripheral blood lymphocytes, Mutat. Res., 259, 133.

Bhosle, S. M., Huilgol, N, G. and Mishra, K. P. (2005) Enhancement of radiationinduced oxidative stress and cytotoxicity in tumor cells by ellagic acid. Clin Chim Acta. 359, 89.

Breen, A. P. and Murphy, J. A. (1995) Reactions of oxyl radicals with DNA. Free Radic. Biol. Med., 18, 1033.

DeKruyff, R., Fang, Y. and Umetsu, D. (1995) IL-4-based helper activity of CD4+ T cells is radiation sensitive. Cell Immunol. 160, 248.

Doan, T., Melvold, R., Viselli, S. and Waltenbaugh, C. (2008) Immunology, Lippincott Williams \& Wilkin (Pub). p. 57.

Fenech, M. (2005) The Genome Health Clinic and Genome Health Nutrigenomics concepts: diagnosis and nutritional treatment of genome and epigenome damage on an individual basis. Mutagenesis, 20, 255.

Fenech, M. and Morely, A. (1985) Measurement of micronuclei in lymphocytes, Mutat. Res., 147, 29.

Fenech, M., Chang, W. P., Krisch-Volders, M., Holland, N., Bonassi, S. and Zeiger, E. (2003) HUMN project: detailed description of the scoring criteria for the cytokinesis-block micronucleus assay using isolated human lymphocyte cultures. Mutat. Res., 534, 65.

Green, L. C., Wagner, D. A., Glogowski, J., Skipper, P. L., Wishnok, J. S. and Tannenbaum, S. R. (1982) Analysis of nitrate,nitrite, and [15N] nitrate in biological fluids. Anal. Biochem., 126, 131.

Gridley, D., Pecaut, M. and Nelson, G. (2002) Total-body irradiation with high-LET particles: acute and chronic effects on the immune system. Am. J. Physiol. Regul. Integr. Comp. Physiol., 282, 677.

Halliwell, B. (2002) Effect of diet on cancer development: is oxidative DNA damage a biomarker? Free Radic. Biol. Med., 32, 968.

Han, S. K., Song, J. Y., Yun, Y. S. and Yi, S. Y. (2005) Ginsan improved Th1 immune response inhibited by gamma radiation. Arch. Pharm. Res. Mar., 28, 343.

Hofseth, L. J. and Wargovich, M. J. (2007) Inflammation, cancer and targets of ginseng. J. Nutr., 137, 183.

Janeway, C. and Travers P. (1997) Immunobiology: the immune system in health and disease. 3 rd Edition. Garland, New York.

Egypt. J. Rad. Sci. Applic., Vol. 28, No. 1-2 (2015) 
Jensh, R. P. (1985) Ionizing radiation and the concept us: neurophysiologic effects of prenatal x-radiation on offspring. Ann. Clin. Lab. Sci., 15, 185.

Jung, N. P. and Jin, S. H. (1996). Studies on the physiological and biochemical effect of Korean ginseng. Korean J. Ginseng Sci., 20, 431.

Kim, S. H., Cho, C. K., Yoo, S. Y., Koh, K. H., Yun, H. G. and Kim, T. H. (1993) In vivo radioprotective activity of Panax ginseng and diethyldithiocarbamate. in Vivo, 7, 467.

Kim, Y. K., Guo, Q. and Packer, L. (2002) Free radical scavenging activity of red ginseng aqueous extracts. Toxicology, 172, 149.

Kitts, D. D., Wijewickreme, A. N. and HU, C. (2000) Antioxidant properties of a North American ginseng extract. Mol. Cell. Biochem., 203, 1.

Kligerman, A. D., Halperin, E. G., Erexson, G. L., Honre, G., Collins, B. and Allen, J. W. (1988) A cytogenetic comparison of the responses of mouse and human peripheral blood lymphocytes to ${ }^{60} \mathrm{Co}$ gamma radiation, Radiât. Res., 115, 334.

Kregel, K. C. and Zhang, H. J. (2007) An integrated view of oxidative stress in aging: basic mechanisms, functional effects and pathological considerations. Am. J. Physiol. Regul. Integr. Comp. Physiol., 292, 18.

Kumar, M., Sharma, M. K., Saxena, P. S. and Kumar, A. (2003) Radioprotective effect of Panax ginseng on the phosphatases and lipid peroxidation level in testes of Swiss albino mice. Biol. Pharm. Bull., 26, 308.

Lee, T., Johnke, R. M., Allison, R. R., O Brien, K. F. and Dobbs, L. J. (2005) Radioprotective potential of ginseng. Mutagenesis, 20, 237.

Lentner, C. (1984) Geigy Scientific Tables, 8Th edition, vol. 3, Publ. Ciba-Geigy Ltd Basle, Switzerland.

Liou, C. J. and Huang, W. C. (2005) Long-term oral administration of ginseng extract modulates humoral immune response and spleen cell functions. Am. J. Chin. Med., 33, 651.

Liou, C. J. and Li, M. L. and Tseng J. (2004) Intraperitoneal injection of ginseng extract enhances both immunoglobulin and cytokine production in mice. Am. J. Chin. Med., 32, 75.

Liou, C. J., Huang, W. C. and Tseng, J. (2005) Long-term oral administration of ginseng extract modulates humoral immune response and spleen cell functions. Am. J. Chin. Med., 33, 651.

Liu, K., Abe, T., Sekine, S., Goto, Y., Iijima, K. and Kondon, K. (1998) Experimental study on the scavenging effects of ginsenosides on oxygen free radicals using model of heterotopic heart transplantation in rats. Ann. Thorac. Cardiovasc. Surg., 4, 188.

McMahon, D. M., Vdovenko, V. Y., Karmaus, W., Kondrashova, V., Svendsen, E., Litvinetz, O. and Stepanova, Y. (2014) Effects of long term low-level 
radiation exposure after the Chernobyl catastrophe on immunoglobulins in children residing in contaminated areas: prospective and cross-sectional studies. Environ. Health, 13, 36.

Myers, C. D. (1991) Role of B cell antigen processing and presentation in the humoral immune response. FASEB. J. 5, 2547.

Ohkawa, H., Ohishi, N. and Yagi, K. (1979) Assay for lipid peroxides in animal tissues by thiobarbituric acid reaction. Anal. Biochem., 95, 351.

Ohta, S., Matsuda, S., Gunji, M. and Kamogawa, A. (2007) The role of nitric oxide in radiation damage. Biol. Pharm. Bull., 30, 1102.

Palmer, R. M., Ashton, D. S. and Moncada, S. (1988) Vascular endothelial cells synthesize nitric oxide from L-arginine. Nature, 333, 664.

Prasad, N. R., Menon, V. P., Vasudev, V. and Pugalendi, K. V. (2005) Radioprotective effect of sesamol on $\gamma$-radiation induced DNA damage, lipid peroxidation and antioxidant levels in cultured human lymphocytes. Toxicology, 209, 225.

Satish Rao, B. S., Shanbhoge, R., Upadhya, D., Jagetia, G. C., Adiga, S. K., Kumar, P., Guruprasad, K. and Gayathri, P. (2006) Antioxidant, anticlastogenic and radioprotective effect of Coleus aromaticus on Chinese hamster fibroblast cells (V79) exposed to gamma radiation. Mutagensis, 21, 237.

Sinkorova, Z., Sinkora, J., Zarybnicka, L., Vilasova, Z. and Pejchal, J. (2009) Radiosensitivity of peripheral blood B cells in pigs. Veterin. Med., 54, 223.

Slifka, M. K., Antia. R., Whitmire, J. K. and Ahmed, R. (1998) Humoral immunity due to long-lived plasma cells. Immunity, $\mathbf{8}, 363$.

Song, X., Zang, L. and Hu, S. (2009) Amplified immune response by ginsenosidebased nanoparticles (ginsomes). Vaccine, 27, 2306.

Taysi, S., Koc, M., Buyukokuroglu, M. E. and Sahin, Y. N. (2003) Melatonin protects rat liver against irradiation-induced injury. J. Radiat. Res., 44, 211.

Weydert, C. J. and Cullen, J. J. (2010) Measurement of superoxide dismutase, catalase and glutathione peroxidase in cultured cells and tissue. Nat. Protoc., 5, 51.

Zhang, X., Yu, L., Bi, H., Li, X., Ni, W., Han, H., Li, N. and Wang, B. (2009) Total fractionation and characterization of the water-soluble polysaccharides isolated from Panax ginseng C.A. Meyer. Carbohydrate Polymers, 77, 544.

(Received: 01/07/2015;

accepted: 16/08/2015)

Egypt. J. Rad. Sci. Applic., Vol. 28, No. 1-2 (2015) 


\section{الجنسنج ، عقار علاجى فعال في مزارع الدم المعرضة لأثسعة \\ جاما}

زينب سالم سيد و شيرين عبد الوهاب منتصر * و محمود محمد أحمد محمود*

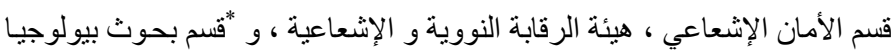

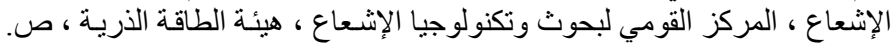

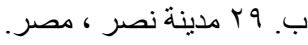

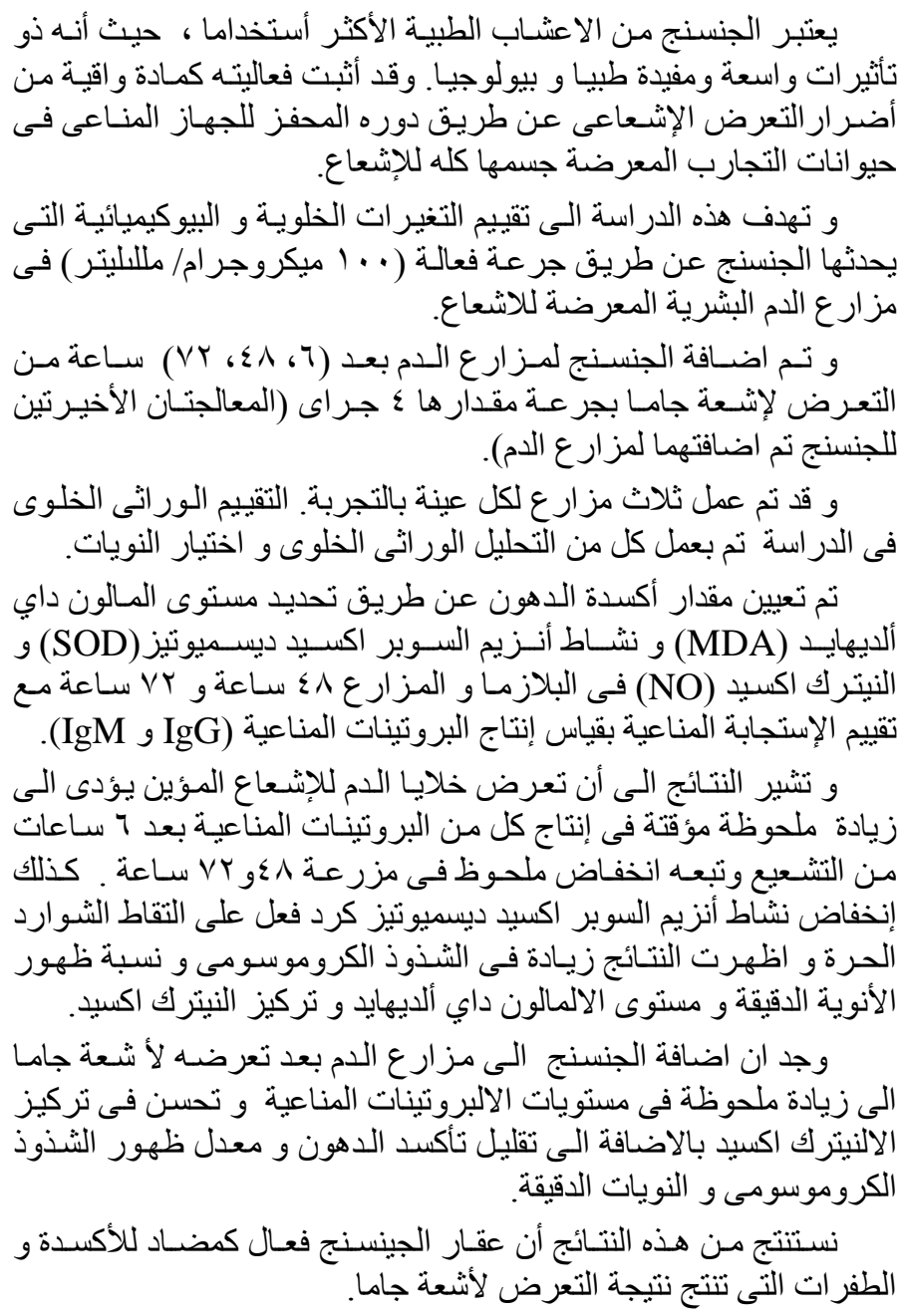

Egypt. J. Rad. Sci. Applic., Vol. 28, No. 1-2 (2015) 